\title{
The Contribution of Islamic Bank in Poverty Alleviation
}

\author{
Lucky Nugroho ${ }^{1}$, Akhmad Amien Mastur ${ }^{2}$, Harnovinsah ${ }^{3}$ Widya Aryanti $^{4}$ \\ 1,2 Program Doktor Islamic Economics and Finance, Universitas Trisakti, Jakarta- \\ Indonesia ${ }^{1,3,4}$ Universitas Mercu Buana, Jakarta-Indonesia \\ e-mail: ${ }^{1}$ lucky.nugroho@mercubuana.ac.id, ${ }^{2}$ amien_mastur@yahoo.co.id, \\ ${ }^{3}$ Harnovinsah@mercubuana.ac.id ${ }^{4}$ widyaaryantiw@gmail.com
}

\begin{abstract}
The existence of Islamic banks as one part of Islamic financial institutions should contribute to improving the economy, one of which is to reduce poverty. Therefore, the purpose of this study is to investigate the effect of financing variables, asset variables, and Islamic bank office variables on poverty levels. The sample used to be Islamic Commercial Banks (BUS) in the 2013-2017 period, with a total of 110 samples. The methodology used is quantitative with multiple regression statistical analysis and statistical data processing using SPSS software version 20. The results of the study note that financing has a negative and significant effect, namely, the higher the financing of Islamic banks, it will reduce poverty. However, the total assets and the number of networks that have a positive and significant effect, namely the increase in total assets and branch networks, it will affect the increasing amount of poverty. That is because the assets of Islamic banks are supported by the majority savings and the not optimal yet of distribution of financing from Islamic banks to the community. Also, the existence of the Islamic branch office tends to be found in provincial capitals and big cities, so that the communities in rural and remote areas are still not reached by Islamic banks.
\end{abstract}

Keywords: Islamic bank financing, Islamic bank asset, Islamic bank branch office; poverty alleviation

Keberadaan bank syariah sebagai salah satu bagian dari lembaga keuangan syariah harus berkontribusi untuk meningkatkan perekonomian, salah satunya adalah mengurangi tingkat kemiskinan. Oleh karena itu tujuan dari penelitian ini adalah untuk mengetahui pengaruh variabel pembiayaan, variabel aset, dan variabel kantor bank syariah terhadap tingkat kemiskinan. Sampel yang digunakan adalah Bank Umum Syariah (BUS) pada periode 2013-2017, dengan total 110 sampel. Metodologi yang digunakan adalah kuantitatif dengan analisis statistik regresi berganda dan pengolahan data statistik menggunakan perangkat lunak SPSS versi 20 . Berdasarkan hasil penelitian, pembiayaan memiliki efeknegatifdan signifikan, yaitu, semakin tinggi pembiayaan bank syariah, maka akan mengurangi kemiskinan. Namun, total aset dan jumlah jaringan memiliki efekpositif dan signifikan, yaitu peningkatan total aset dan jaringan cabang, berpengaruh terhadap meningkatnya jumlah kemiskinan. Hal tersebut dikarenakan struktur aset bank syariah didominasi oleh tabungan dan belum optimalnya distribusi pembiayaan dari bank syariah kepada masyarakat. Selain itu, keberadaan kantor cabang dari bank syariah cenderung ditemukan di ibu kota provinsi dan kota-kota besar, sehingga masyrakat di daerah pedesaan dan terpencil masih belum terjangkau oleh bank syariah.

Keywords: pembiayaan banksyariah, asetbanksyariah,jaringan kantor bank syariah, tingkat kemiskinan 


\section{Introduction}

The development has a vital role in a country throughout the world. The purpose of development in a country is to improve the welfare of its people. ${ }^{1}$ In developed countries, development in the industrial sector is no longer a priority of the government. Developed countries have entered the post-industrialization stage, where the majority of developed countries prioritize the service sector as the main contribution to the economy. This is different from developing countries where the industrial sector is the most significant contributor to the economy. Also, developed countries have per capita incomes that are sufficient to meet minimum living standards and also have adequate infrastructure and have a high human development index (HDI). While developing country conditions have different characteristics with developed countries. The developing countries are characterized by inadequate per capita income for all residents to live appropriately. Likewise, the HDI level is still lagging behind developed countries. Thus, the welfare of the population in developed countries is more guaranteed when compared to developing countries. ${ }^{2}$

Indonesia, with the 4th largest population in the world with the largest Moslem population, amounting to 203 million people in 2017 or $88 \%$ of the total population of Indonesia (graph 1), is included in developing industrial countries.

\footnotetext{
${ }_{1}^{1}$ Maryann P. Feldman, "The Character of Innovative Places: Entrepreneurial Strategy, Economic Development, and Prosperity', Small Business Economics 43, no. 1 (March 2014): 11, https://doi.org/ 10.1007/s11187-014-9574-4.

${ }^{2}$ Nicholas; Aprajit Mahajan; David McKenzi; John Roberts Bloom, 'Why Do Firms in Developing Countries Have Low Productivity?', American Economic Review 100, no. 2 (2010): 622, https://doi.org/10.1257/aer.100.2.619; Ilhan Ozturk, Alper Aslan, and Huseyin Kalyoncu, 'Energy Consumption and Economic Growth Relationship: Evidence from Panel Data for Low and Middle Income Countries', Energy Policy 38, no. 8 (August 2010): 4427, https://doi.org/10.1016/ j.enpol.2010.03.071; Yoghi Citra Pratama, 'Analisis Faktor-Faktor yang Mempengaruhi Kemiskinan di Indonesia', Esensi: Jurnal Bisnis dan Manajemen 4, no. 2 (2014): 211.
} 
Graph 1. Number of Moslems in Every Country in the World in 2017 (in a million)

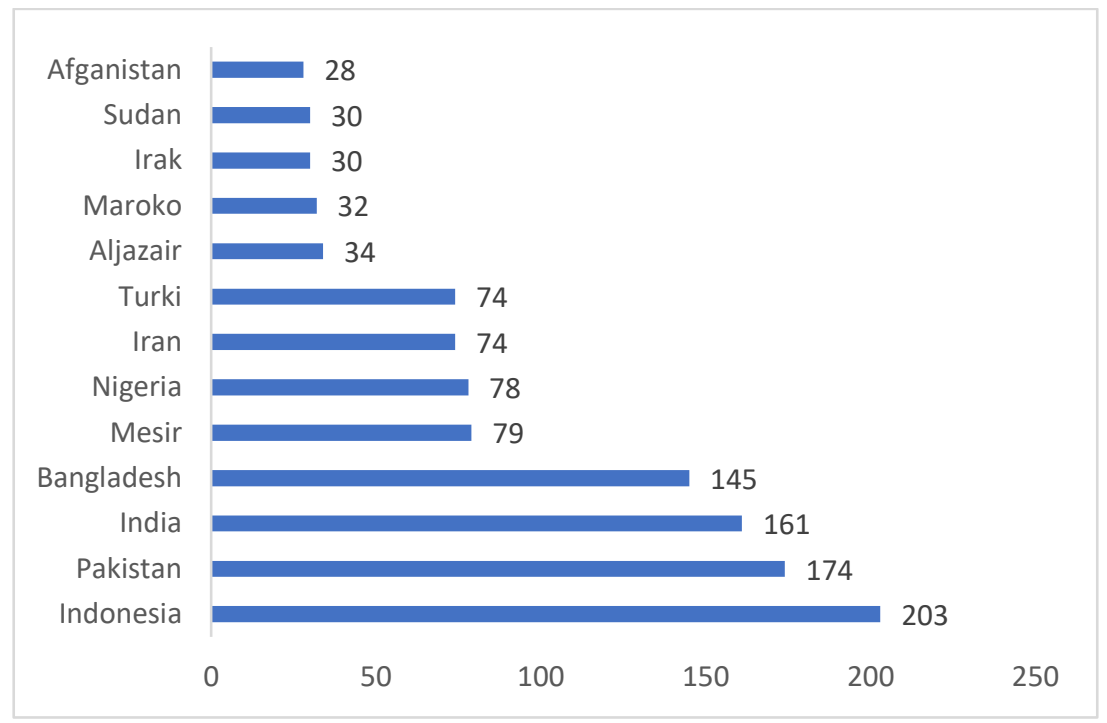

Source: ${ }^{3}$

Refers to research conducted by, ${ }^{4}$ states that developing countries are due to inadequate per capita income to meet the welfare of their people, then some social problems arise in the country. These social problems include poverty, unemployment, low education, and low-quality health services. ${ }^{5}$ Therefore, development in Indonesia, one of which aims to reduce poverty. The definition of poverty is a condition where a person or group of people has not been able to meet the minimum level of living needs. To alleviate poverty, the government must carry out development comprehensively from various social aspects of community life. The poverty data in Indonesia in the 2013-2017 period are as follows:

3TribunJogja, 'Penelitian : Islam Agama dengan Pertumbuhan Paling Cepat di Dunia - Tribun Jogja', jogja.tribunnews.com, 2017.

${ }^{4}$ Armando Barrientos, Mark Gorman, and Amanda Heslop, 'Old Age Poverty in Developing Countries: Contributions and Dependence in Later Life', World Development 31, no. 3 (March 2003): 555-70, https://doi.org/10.1016/S0305-750X(02)00211-5.

5Paula Santana, 'Poverty, Social Exclusion and Health in Portugal', in Social Science and Medicine, vol. 55 (Pergamon, 2002), 33-45, https://doi.org/10.1016/S0277-9536(01)00218-0; Mohammad Mulyadi, 'Peran Pemerintah dalam Mengatasi Pengangguran dan Kemiskinan dalam Masyarakat', Kajian 21, no. 3 (2016): 221-36. 


\section{Graph 2. Percentage of Poverty Rate in Indonesia in 2013-2017}

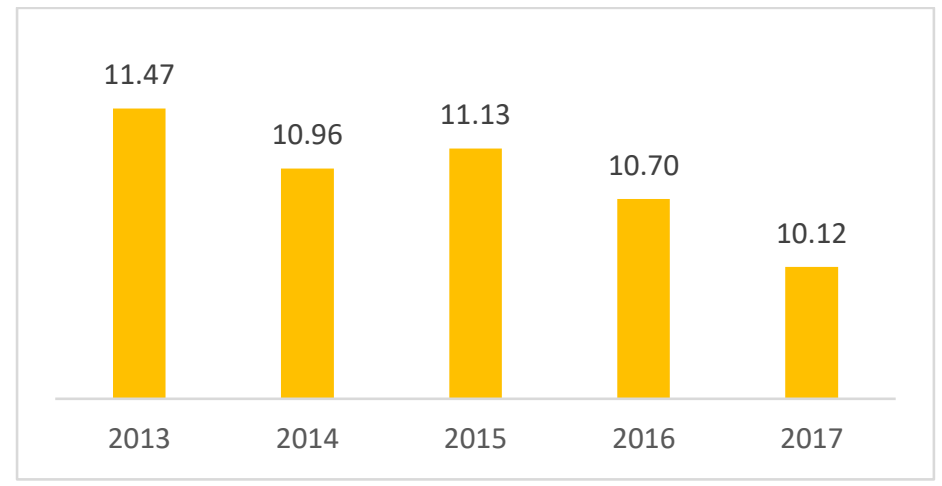

Sourch:6

Referring to graph two above, it can be explained that the poverty rate for the period of 2013 to 2017 experienced a downward trend. While the increase in poverty in 2015 was due to rising rice commodity prices and was accompanied by global economic turmoil. However, according to the head of the Central Statistics Agency (BPS), after the government social program has been carried out and also anticipatory measures to increase inflation since 2014, the number of poor people coming out of the poor category began to improve, so that from 2015 to 2017 the poverty level continues to decrease.7

On the other hand, the Indonesian government has the desire of Indonesia as a center for Islamic finance, one of which is to improve the welfare of the Indonesian people, where the plan is in line with the basic concept of Islamic finance, to realize social-wellbeing or create a prosperous society (hadarah) which have fulfilled the spiritual and intellectual aspects (tamadun and thaqafah). ${ }^{8}$ Furthermore, Islamic banking which is also part of Islamic financial

${ }^{6}$ BPS, 'Angka Kemiskinan Indonesia Sentuh 9,66\%, Terendah Sepanjang Sejarah | Databoks', Katadata.co.id, 2019. 2016.

${ }^{7}$ Lily Rusna Fajriah, 'Angka Kemiskinan Meningkat Tembus 28,51 Juta Orang', sindonews.com,

${ }^{8}$ Hamid Fahmy Zarkasyi, ‘Tamaddun Sebagai Konsep Peradaban Islam', Tsaqafah 11, no. 1 (2015): 1-28; Mehmet Asutay, 'Conceptualisation of the Second Best Solution in Overcoming the Social Failure of Islamic Banking and Finance: Examining the Overpowering of Homoislamicus by Homoeconomicus.', Journal of Economic and Management 15, no. 2 (2007): 167-95; Masudul Alam Choudhury and Md Mostaque Hussain, 'A Paradigm of Islamic Money and Banking', International Journal of Social Economics 32, no. 3 (2005): 203-17, https://doi.org/10.1108/ 030682905105 
institutions has different objectives from conventional banks, where the activities of Islamic banks aim to reach falah, namely all stakeholders of Islamic banks can carry out their beliefs in a kaffah and totality so that they get safety in the world and happiness in the hereafter. ${ }^{9}$ Therefore, Islamic banks are banks that are pro and have a focus on alleviating poverty through its products and services. In carrying out its functions, the bank has a core business to manage the third party funds it gets to be distributed back to the public. ${ }^{10}$ Therefore, in the context of poverty alleviation, the more Islamic bank financing that is channeled to the community, it will contribute to the improvement of people's welfare, which incidentally decreases the poverty rate ${ }^{11}$. Also, the existence of the banking industry is reflected by the size of assets, where the higher the assets owned by the bank, the higher its role in the economy of the country, even shocks to the bank will result in systemic risk ..$^{12}$ Thus, the higher the assets of Islamic banks, the more significant their contribution to the economy and the impact on decreasing the number of poor people ${ }^{13}$. On the other hand, the

80760; Lucky Nugroho, Wiwik Utami, and Caturida Meiwanto Doktoralina, 'Ekosistem Bisnis Wisata Halal Dalam Perspektif Maqasid Syariah (Halal Tourism Business Ecosystem in the Maqasid Syariah Perspective)', Perisai: Islamic Banking and Finance Journal 3, no. 2 (2019): 84-92, https://doi.org/ 10.21070/perisai.v3i2.1964.

9Elsa Satibi, Wiwik Utami, and Lucky Nugroho, 'A Comparison of Sharia Banks and Conventional Banks in Terms of Efficiency, Asset Quality and Stability in Indonesia for the Period 2008-2016', International Journal of Commerce and Finance 4, no. 1 (2018): 134-49; Lucky Nugroho, Ahmad Badawi, and Nurul Hidayah, 'Indonesia Islamic Bank Profitability 2010-2017', Shirkah Journal of Economics and Business 4, no. 1 (2019): 75-99.

${ }^{10}$ Lucky Nugroho and Dewi. Tamala, 'Persepsi Pengusaha UMKM terhadap Peran Bank Syariah', Jurnal SIKAP (Sistem Informasi, Keuangan, Auditing Dan Perpajakan) 3, no. 1 (2018): 49-62; Asyraf Wajdi Dusuki, 'Understanding the Objectives of Islamic Banking: A Survey of Stakeholders' Perspectives', International Journal of Islamic and Middle Eastern Finance and Management 1, no. 2 (2008): 132-48, https://doi.org/10.1108/17538390810880982.

${ }^{11}$ Delima Sari Lubis, 'Pemberdayaan UMKM Melalui Lembaga Keuangan Syariah sebagai Upaya Pengentasan Kemiskinan Kota Padangsidimpuan', At-Tijaroh:Jurnal Ilmu Manajemen Dan Bisnis Islam 2, no. 2 (2016): 270-85; Lucky Nugroho, Nurul Hidayah, and Ahmad Badawi, 'Discourses of Sustainable Finance Implementation in Islamic Bank (Cases Studies in Bank Mandiri Syariah 2018)', International Journal of Financial Research 10, no. 6 (2019): 108-17, https://doi.org/10.5430/ ijfr.v10n6p108.

${ }^{12}$ Franklin Allen, Ana Babus, and Elena Carletti, 'Asset Commonality, Debt Maturity and Systemic Risk', Journal of Financial Economics 104, no. 3 (June 2012): 519-34, https://doi.org/10.1016/ j.jineco.2011.07.003.

${ }_{13}$ Roszaini Haniffa and Mohammad Hudaib, 'Exploring the Ethical Identity of Islamic Banks via Communication in Annual Reports', Journal of Business Ethics 76, no. 1 (November 2007): 97-116, https://doi.org/10.1007/s10551-006-9272-5. 
presence of a bankis also shown by the number of offices, the wider the network owned by the bank, even if it can reach rural and remote areas, then the existence of the bank is serving the community will be more beneficial for the economy of the disadvantaged regions and the rural regions. ${ }^{14}$

Following this phenomenon, the formulation of the problem in this study is (i) Does the amount of Islamic bank financing affect the level of poverty?; (ii) Does the Islamic bank assets affect the level of poverty?; (iii) Does the number of Islamic bank networks or offices affect poverty levels? Thus, the purpose of this study is to investigate the influence of Islamic banks in terms of financing, assets, and office networks they have on poverty levels. The contribution of this research is for all stakeholders who have concerns for Islamic banks to increase their contribution to the Indonesian economy. Moreover, it can be used for further researchers on the topic of Islamic banks and poverty.

\section{Literature Review}

The Qur'an is the main source of law in Islam which is always relevant for every time and place. ${ }^{15}$ In its application, the Koran must be accompanied by Hadith and also ijtihād from the scholars. In addition to implementing the Koran, Hadith and Ijtihad must be accompanied by sufficient knowledge, so that its application to religious life that aims to create benefits for society can be realized. Therefore, in carrying out this dynamic life, Muslims must have the concept of being the best human beings by applying the teachings of enjoining good and forbidding evil (al-amr bi al-ma'rüf wa al-nahy 'an al-munkar), and believers to Allah (tu'minūn billāh). That is as written in Âli 'Imrān verse 110.

Islam, as a religion of justice, has a holistic concept in overcoming the gap between rich and poor, namely through social activities. The solution to social problems related to economics, in Islam, can be through equity distribution

\footnotetext{
${ }^{14}$ Allen N. Berger, Gerald A. Hanweck, and David B. Humphrey, 'Competitive Viability in Banking. Scale, Scope, and Product Mix Economies', Journal of Monetary Economics 20, no. 3 (December 1987): 501-20, https://doi.org/10.1016/0304-3932(87)90039-0; Roy Mersland, Trond Randøy, and Reidar Øystein Strøm, 'The Impact of International Influence on Microbanks' Performance: A Global Survey', International Business Review 20, no. 2 (April 2011): 163-76, https://doi.org/10.1016/ j.ibusrev.2010.07.006.

15Willy Arafah and Lucky Nugroho, 'Maqhashid Sharia in Clean Water Financing Business Model at Islamic Bank, International Journal of Business and Management Invention (IJBMI) 5, no. 2 (May 2016): $22-32$.
} 
operations, such as zakat, infaq, shadaqah, and endowments. Based on the implementation of these social channels, the problem of inequality in the economy must be eliminated. Islam is a religion that provides prosperity for all people. Therefore, poverty alleviation is a problem for fellow Muslims to help their brothers and sisters in reducing poverty. The order is stated in Al-Baqarah verse 267 and Āli 'Imran verse 92.

The concept of Islamic finance is a business and commercial activity based on the tawhid dimension so that the basis of the guidelines and references are the Qur'an and As-Sunnah. Likewise, Islamic banks, which are Islamic financial institutions, have responsibilities towards commercial implementation, in this case channeling financing by sharia objectives. The purpose of sharia in the distribution of financing is to provide benefits to the community. The allocation of funding will provide benefits if the impact of financing can contribute to the welfare, which will reduce poverty levels. Refer to research conducted by ${ }^{16}$, Islamic banks do not yet have a focus on channeling financing to the MSME sector so that the impact of the presence of Islamic banks in improving the welfare of MSME actors is relatively insignificant. Islamic banks following their khittah (basic concept) are banks that have a concern for the social aspects and environmental aspects such as the poor and ecological sustainability. ${ }^{17}$ That is because the existence of Islamic banks in carrying out their functions is as an agent of change that supports public financial transactions having the principles of maqāșid al-sharīa, ${ }^{18}$ namely: (i) maintaining religion; (ii) maintaining soul; (iii) maintaining reason; (iv) maintaining descendant; (v) maintaining property; (vi) protect the environment.

\footnotetext{
${ }^{16}$ Lucky Nugroho and Ahmad Badawi, "The Islamic Banking, Asset Quality: "Does Financing Segmentation Matters" (Indonesia Evidence)', Mediterranean Journal of Social Sciences 9, no. 5 (2018): 221-35, https://doi.org/10.2478/mjss-2018-0154.

${ }^{17}$ Sirajo Aliyu etal., 'Islamic Banking Sustainability: A Review of Literature and Directions for Future Research', Emerging Markets Finance and Trade 53, no. 2 (February 2017): 440-70, https://doi.org/10.1080/1540496X.2016.1262761; Michael S. Bennettand Zamir Iqbal,'How Socially Responsible Investing Can Help Bridge the Gap Between Islamic and Conventional Financial Markets', International Journal of Islamic and Middle Eastern Finance and Management 6, no. 3 (August 2013): 211-25, https://doi.org/10.1108/IMEFM-Aug-2012-0078.

18Maskur Rosyid and M. Nurul Irfan, 'Reading Fatwas of MUI a Perspective of Maslahah Concept', Syariah: Jurnal Hukum Dan Pemikiran 19, no. 1 (2 June 2019): 93-94.
} 
Financial institutions have strict regulations because of their function to raise funds from the community so that prudential principles are needed in managing their funds. With proper management of these funds, it will increase public confidence. Public trust for banks is vital to maintain the bank's liquidity. If the community does not have trust in the bank, then the deposits contained in the bank will be withdrawn, which will have an impact on the bank will collapse because it is unable to return public deposits in a short period. The more people trust the bank, the higher the savings in the bank so that it contributes to the increase in assets of the bank. The source of funds from the savings will be distributed in the form of financing. Thus, the amount of savings will increase the ability of banks to allocate funds to the public and also have implications for increased income. By the objectives of Islamic banks where the activities and operations of Islamic banks aim to provide mercy to all people, the increase in bank assets will provide the flexibility of banks to conduct business and activities to improve the welfare of the ummah as stipulated in Al-Anbiyā verse 107:

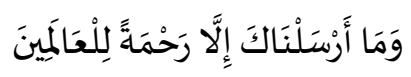

"And We have not sent you, [O Muhammad], except as a mercy to the worlds"

Referring to the Qur'anic verse, the existence of an Islamic bank will be more beneficial compared to conventional banks. Islamic banks have special products for the poor. ${ }^{19}$ Besides that, Islamic banks are banks that uphold the value of justice so that it can be one of the solutions in preventing economic crises caused by one of them is the element of human greed in commercial activities. ${ }^{20}$ Islamic bank services should reach all rural and remote areas that need support from Islamic banks. Islamic banks are not only banks that provide financial services based on sharia principles, but they are financial institutions that aim to

\footnotetext{
${ }^{19}$ Arafah and Nugroho, 'Maqhashid Sharia in Clean Water Financing Business Model at Islamic Bank, 30.

20Dian Masyita, 'Why Do People See A Financial System As A Whole Very Important?', Journal of Islamic Monetary Economics and Finance 1, no. 1 (2015): 89; Khairul Mukminin, 'Profit Maximization in Islamic Banking: An Assemblage of Maqasid Shariah Conception', Profit Maximization in Islamic Banking: An Assemblage of Maqasid Shariah Conception, no. 12 (2019): 7, https://doi.org/ 10.13135/2421-2172/2856; Nugroho and Tamala,'Persepsi Pengusaha UMKM terhadap Peran Bank Syariah', 54 .
} 
complement the teachings of Islam. Thus, all Moslems can carry out their instructions in a käffah or totality. The breadth of coverage of the Islamic bank branch offices, the more people who get services from Islamic banks so that it will be more beneficial to the community. Thus, the framework of thought in this study can be illustrated in figure 1 below:

\section{Figure 1. Conceptual Research Framework}

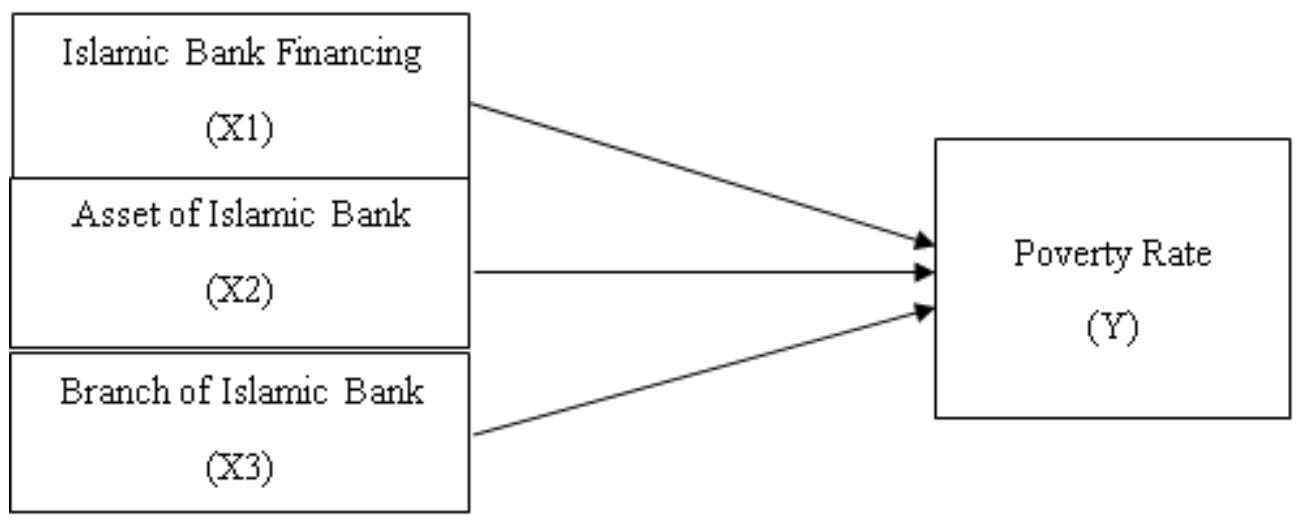

Referring to figure 1 above, the hypotheses in this study include:

- H1: Islamic bank financing affects the Poverty Rate;

- H2: The total assets of Islamic banks influence the Poverty Rate;

- H3: The number of outlets or office networks of Islamic banks affects the Poverty Rate.

Based on the conceptual framework in Figure 1, the formula of the multiple regression equation in this study is as follows:

$$
Y=a+\beta 1 X 1+\beta 2 X 2+\beta 3 X 3+e
$$

The description of the symbols are:

$\mathrm{Y}=\quad$ Poverty level;

$a, \beta 1, \beta 2, \beta 3=\quad$ Regression coefficient;

$\mathrm{X} 1=\quad$ Islamic bank financing;

$\mathrm{X} 2=\quad$ Assets of Islamic banks;

$\mathrm{X} 3=\quad$ Number of Islamic bank office;

$\mathrm{e}=\quad$ Other variable values, not included in the study 
This study uses secondary data types in the form of publication reports (reports per semester) from Islamic commercial banks in 2013-2017 which are registered with the Financial Services Authority (OJK) and Bank Indonesia. Data is obtained by downloading financial reports from the websites of Bank Indonesia and OJK at www.bi.go.id and www.ojk.go.id, while the dependent variable data comes from the Central Statistics Agency website (www.bps.go.id). All sharia commercial banks in Indonesia comprise the population in this study, as many as 13 Islamic commercial banks. Determination of the sample is done using a purposive sampling method with the following criteria.

- Islamic Commercial Bank (BUS) registered with Bank Indonesia (BI) or the Financial Services Authority (OJK);

- Islamic Commercial Bank (BUS) that publishes financial statements for the period of 2013-2017 published in BI or OJK;

- Financial statements contain information and can provide the necessary data for the 2013-2017 period.

Based on the above criteria, the sample used in this study was 11 BUS, are those 1) PT Bank Victoria Syariah, 2) PT Bank BRI Syariah, 3) PT Bank Jabar Banten Syariah, 4) PT Bank BNI Syariah, 5) PT Bank Syariah Mandiri, 6) PT Bank Mega Syariah, 7) PT BankPanin Syariah, 8) PT Bank Syariah Bukopin, 9) PT Bank BCA Syariah, 10) PT Maybank Indonesia Syariah, 11) PT Bank Muamalat Indonesia. While the amount of data obtained was 110 samples. The data was analyzed by quantitative methods in the form of statistical analysis to investigate the effect of financing, total assets, and the number of sharia bank offices on poverty levels. Statistical analysis of the data used in this study includes descriptive statistical tests, normality tests, heteroscedasticity tests, and multiple linear regression statistical tests using the SPSS version 20 application.

\section{Results and Discussion}

The results of statistical data processing using SPSS version 20 for descriptive statistics can be known as the following information:

Table I. Statistical Descriptive Test Results

\begin{tabular}{|c|c|c|c|c|c|}
\hline & $\mathrm{N}$ & Minimum & Maximum & Mean & Std. Deviation \\
\hline Financing & 110 & 13.1621 & 18.1600 & 15.745732 & 1.3213647 \\
Asset & 110 & 13.6783 & 18.2474 & 15.940649 & 1.2781322 \\
Office Branch & 110 & 1.0000 & 712.0000 & 174.027273 & 206.7568469 \\
Poverty Rate & 110 & .1012 & .1147 & .109720 & .0038816 \\
Valid N (listwise) & 110 & & & & \\
\hline
\end{tabular}


Referring to Table III above, the average of the financing variable of Islamic banks (X1) is 15.745732, with a standard deviation of 1.3213647 and a maximum value of 18.1600 and a minimum value of 13.1621 . The maximum value occurs in September 2017, namely PT. Bank Syariah Mandiri of 18.1600 and the minimum value occurred in March 2013, namely PT. Bank Victoria Syariah amounted to 13.1621. This is that PT. Bank Syariah Mandiri is the largest Islamic bank in Indonesia. Also, the total assets variable (X2) was 15.940649, with a standard deviation of 1.27131322 and a maximum value of 18.2474 and a minimum value of 13.66783 . The maximum value occurs in September 2017, namely PT. Bank Syariah Mandiri amounted to 18,2474, and the minimum value occurred in March 2013, namely PT. Bank Victoria Syariah amounted to 13,678. The data also shows that PT. Bank Syariah Mandiri as the largest Islamic bank in Indonesia in terms of assets, while PT. Bank Victoria Syariah is the smallest Islamic bank in terms of assets. While the variable number of offices (X3), the average number of 174 offices with a standard deviation of 206.7568469 and a maximum value of 712 offices and a minimum value of 1,0000. The maximum value occurs in March and September 2015, namely PT. Bank Syariah Mandiri amounted to 712 offices, and the minimum value occurred in March 2013 to September 2017, namely PT. Maybank Indonesia Syariah for one office. Thus, PT. Bank Syariah Mandiri is an Islamic bank that has the most office networks in Indonesia. ${ }^{21}$

However, the statistical test results related to data normality obtained information as follows:

Table II. Statistical Test Results Normality Data

\begin{tabular}{|c|c|c|}
\hline & & Unstandardized Residual \\
\hline $\mathrm{N}$ & & 110 \\
\hline & Mean & $0 \mathrm{E}-7$ \\
\hline Normal Parameters & Std. Deviation & 00359898 \\
\hline & Absolute & ,094 \\
\hline Most Extreme Differences & Positive & ,065 \\
\hline & Negative &,- 094 \\
\hline Kolmogorov-Smirnov Z & & ,988 \\
\hline Asymp. Sig. (2-tailed) & & ,284 \\
\hline
\end{tabular}

a. Test distribution is Normal.

b. Calculated from data.

\footnotetext{
${ }^{21}$ Lucky Nugroho et al., 'Maslahah and Strategy to Establish a Single State-Owned Islamic Bank in Indonesia', Tazkia Islamic Finance and Business Review 10, no. 1 (2017): 30-33; Mustika Rimadhani and Osni Erza, 'Analisis Variabel-Variabel yang Mempengaruhi Pembiayaan Murabahah pada Bank Syariah Mandiri Periode 2008.01-2011.12', Media Ekonomi 19, no. 1 (2011): 40-42.
} 
Refer to table IV above for the magnitude of the Asymp value. Sig. (2-tailed) is $0.284>0.05$. This shows that the data is normally distributed.

Also, a heteroscedasticity statistical test was performed, which aimed to test whether, in the regression model, there was an inequality of residual variance from one observation to another. If all variables have a significant value above 0.05 , then there is no symptom of heteroscedasticity. The test uses the glacier test to examine it.

Table III. Glejser Statistical Test Results

\begin{tabular}{|ll|c|c|}
\hline \multicolumn{1}{|c|}{ Model } & $\mathrm{T}$ & Sig. \\
& & \\
\hline \multirow{2}{*}{1 (Constant) } &,- 817 &, 416 \\
Financing & $-1,254$ &, 212 \\
& Assets & 1,458 &, 148 \\
& Branch Offices & $-1,359$ &, 177 \\
\hline
\end{tabular}

a. Dependent Variable: ABS_RES

Based on the results of the output table $\mathrm{V}$ above, it can be seen that all variables have a significance value of more than $5 \%$, which means there are no symptoms of heteroscedasticity between independent variables.

Furthermore, to determine the effect of the independent variables in this study on poverty levels, a regression test was carried out with the following information:

Table IV. Multiple Linear Regression Statistical Test Results

Coefficients $^{\mathbf{a}}$

\begin{tabular}{|c|c|c|c|c|c|}
\hline \multirow[t]{2}{*}{ Model } & \multicolumn{2}{|c|}{ Unstandardized Coefficients } & \multirow{2}{*}{$\begin{array}{c}\begin{array}{c}\text { Standardized } \\
\text { Coefficients }\end{array} \\
\text { Beta }\end{array}$} & \multirow[t]{2}{*}{$\mathrm{t}$} & \multirow[t]{2}{*}{ Sig. } \\
\hline & B & Std. Error & & & \\
\hline (Constant) & 124 & ,008 & & 16,578 & 000 \\
\hline 1 Financing &,- 007 & ,002 & $-2,304$ & $-2,817$ & ,006 \\
\hline Assets & ,006 & ,002 & 1,826 & 2,222 & ,028 \\
\hline Branch Offices & 002 & 001 & ,408 & 2,279 &, 025 \\
\hline
\end{tabular}

a. Dependent Variable: Poverty Rate

By table VI above, the model of the results of the multiple linear regression analysis used in this study can be formulated as follows:

$$
Y=0,124-0,007 X 1+0,006 X 2+0,002 X 3+e
$$


Following the regression results above, it can be seen that financing has a negative and significant effect on poverty levels. This shows that an increase in the amount of financing in Islamic banks will contribute significantly to a decrease in the amount of poverty. Thus, the distribution of Islamic bank financing has been right on target where the use of funds provided by Islamic banks to customers has been able to improve the welfare of customers of the Islamic bank. Therefore, the existence of Islamic banks in Indonesia must be supported by the government to help the government reduce poverty. The government should provide policies and stimulus for Islamic banks in channeling financing so that the portion of financing from Islamic banks can be more significant than lending from conventional banks. This is due to the distribution of Islamic bank financing based on fair contracts and also based on underlying assets so that the distribution of Islamic bank financing will have a direct impact on the real sector. The results of this study are in line with the concept of Islamic banks as banks that provide benefits to the Ummah. ${ }^{22}$ The concept of Islamic banks has a difference with conventional banks. That is because Islamic banks have a legal basis and objectives (maqūșid al-sharīa) that are different from conventional banks. The legal basis of Islamic banks is the Qur'an and Hadith, so the operations of Islamic banks must refer to the legal basis. Islam, as a religion, governs all aspects of people's lives aimed at securing salvation in the world and happiness in the hereafter. Also, Islamic banks as banks that have different goals from conventional banks because Islamic banks are not only aimed at profit only but also provide welfare for the human and are socially oriented 23

On the other hand, the variable amount of assets of Islamic banks has a significant and positive influence on poverty levels. This can be caused by a decrease in the financing deposit ratio continuously for three years from 2013 to 2016, which is shown in the graph below:

\footnotetext{
${ }^{22}$ Arafah and Nugroho, 'Maqhashid Sharia in Clean Water Financing Business Model at Islamic Bank', 25-30; Nugroho et al., 'Maslahah and Strategy to Establish a Single State-Owned Islamic Bank in Indonesia', 28-30; Asyraf Wajdi Dusuki, 'Banking for the Poor: The Role of Islamic Banking in Microfinance Initiatives', ed. Masudul Alam Choudhury, Humanomics 24, no. 1 (February 2008): 4966, https://doi.org/10.1108/08288660810851469.

${ }^{23}$ Asutay, 'Conceptualisation of the Second Best Solution in Overcoming the Social Failure of Islamic Banking and Finance: Examining the Overpowering of Homoislamicus by Homoeconomicus.', 83, 95, 134.
} 


\section{Graph 3. Percentage of Financing Deposit Ratio (FDR) in the 2012-2016 Period}

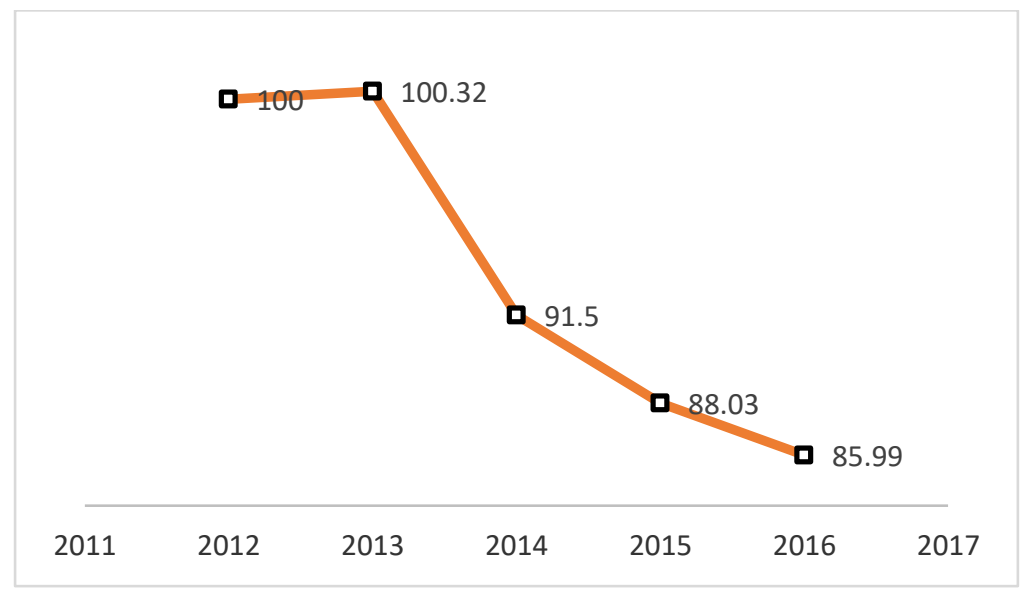

Source: Financial Services Authority (OJK) that has been processed

Referring to graph three above, it can be seen that the function of the distribution of Islamic banks has decreased performance for three years in a row, namely the 2013-2016 period. This condition causes an increase in the assets of Islamic banks to be contributed by the addition of deposits from third parties or deposits. Thus, the impact of adding Islamic bank assets has significant implications for the increase in poverty. Therefore, the government as regulation should measure the performance of Islamic banks not only in terms of asset growth but also how the impact of the growth of these assets on reducing poverty ${ }^{24}$. Likewise, the stakeholders of Islamic banks, the target of Islamic bank performance, should be the impact is not solely the numbers on the financial statements in the form of assets, but the importance is the substance of the existence of Islamic banks is to provide benefits for the human race.

Islamic bank office network is the frontline to provide Islamic financial services. A large number of networks and services of Islamic banks in all corners

${ }^{24}$ Dwi Agung Nugroho Arianto, 'Peranan Al-Mudharabah sebagai Salah Satu Produk Perbankan Syariah dalam Upaya Mengentaskan Kemiskinan di Indonesia', Jurnal Ekonomi \& Pendidikan 8, no. 2 (2011): 124-41, https://doi.org/10.1007/978-90-481-2532-6_2; Caturida Meiwanto Doktoralina and Fikki Mutarotun Nisha, 'Mudharabah Deposits Among Conventional Bank Interest Rates, ProfitSharing Rates, Liquidity and Inflation Rates', International Journal of Financial Research 11, no. 1 (2020): 25-33, https://doi.org/10.5430/ijfr.v11n1p25. 
of the country will have an impact on the increasing literacy of Islamic finance and also the use of Islamic bank products and services by the public in Indonesia. However, the results of this study provide information that the expansion of the Islamic bank network has a positive and significant impact on increasing poverty. The results of the statistical test stated that the addition of office networks of Islamic banks did not contribute to reducing poverty. Thus, there is the possibility of a feasibility mechanism (feasible study) of opening an office network of Islamic banks, which are located in provincial cities, and large towns only consider the profit factor alone. Therefore, it can be possible that the focus of Islamic banks is on the middle to the upper-class segment where the majority of them live in big cities and provinces rather than in rural or remote areas in Indonesia.

\section{Conclusions}

The existence of Islamic banks should be the focus of the government to become partners in alleviating poverty jointly. This is in line with the results of this study, especially on the variable distribution of Islamic bank financing. Increased allocation of Islamic banks can reduce poverty levels, where the distribution of Islamic bank financing will have a direct impact on the real sector so that it will increase economic growth. Other variables in this study are the number of Islamic bank assets, and the number of office networks of Islamic banks has a positive and significant impact on the increase in poverty. This shows that currently, the growth of Islamic bank assets is supported by deposits and studies on the opening of office networks of Islamic banks that have not been comprehensively assessed by considering the benefit of the people.

Thus, this research can be taken into consideration for all stakeholders in establishing Islamic bank performance indicators that are not only based on a large number of assets and profits generated but also consider aspects of the contribution of Islamic banks to the benefit of the people. Also, the results of this study can be used by subsequent researchers who have Islamic banking themes and social problems with different variables and periods from this study.[a] 
Lucky Nugroho, Akhmad Amien Mastur, Harnovinsah, Widya Aryanti

\section{BIBLIOGRAFI}

Aliyu, Sirajo, M. Kabir Hassan, Rosylin Mohd Yusof, and Nasri Naiimi. 'Islamic Banking Sustainability: A Review of Literature and Directions for Future Research'. Emerging Markets Finance and Trade 53, no. 2 (February 2017): 440-70. https://doi.org/10.1080 /1540496X.2016.1262761.

Allen, Franklin, Ana Babus, and Elena Carletti. 'Asset Commonality, Debt Maturity and Systemic Risk'. Journal of Financial Economics 104, no. 3 (June 2012): 519-34. https://doi.org/10.1016/j.jfineco.2011.07. 003 .

Andriyanto, Irsyad. 'Strategi Pengelolaan Zakat dalam Pengentasan Kemiskinan'. Jurnal Walisongo 19, no. 1 (2011): 25-46.

Arafah, Willy, and Lucky Nugroho. 'Maqhashid Sharia in Clean Water Financing Business Model at Islamic Bank'. International Journal of Business and Management Invention (IJBMI) 5, no. 2 (May 2016): 2232.

Arianto, Dwi Agung Nugroho. 'Peranan Al-Mudharabah sebagai Salah Satu Produk Perbankan Syariah dalam Upaya Mengentaskan Kemiskinan di Indonesia'. Jurnal Ekonomi \& Pendidikan 8, no. 2 (2011): 124-41. https://doi.org/10.1007/978-90-481-2532-6_2.

Asutay, Mehmet. 'Conceptualisation of the Second Best Solution in Overcoming the Social Failure of Islamic Banking and Finance: Examining the Overpowering of Homoislamicus by Homoeconomicus.' Journal of Economic and Management 15, no. 2 (2007): 167-95.

Barrientos, Armando, Mark Gorman, and Amanda Heslop. 'Old Age Poverty in Developing Countries: Contributions and Dependence in Later Life'. World Development 31, no. 3 (March 2003): 555-70. https://doi.org/10.1016/S0305-750X(02)00211-5.

Bennett, Michael S., and Zamir Iqbal. 'How Socially Responsible Investing Can Help Bridge the Gap Between Islamic and Conventional Financial Markets'. International Journal of Islamic and Middle Eastern Finance and Management 6, no. 3 (August 2013): 211-25. https://doi.org/10.1108/IMEFM-Aug-2012-0078.

Berger, Allen N., Gerald A. Hanweck, and David B. Humphrey. 'Competitive Viability in Banking. Scale, Scope, and Product Mix Economies'. Journal of Monetary Economics 20, no. 3 (December 1987): 501-20. 
https://doi.org/10.1016/0304-3932(87)90039-0.

Bloom, Nicholas; Aprajit Mahajan; David McKenzi; John Roberts. 'Why Do Firms in Developing Countries Have Low Productivity?' American Economic Review 100, no. 2 (2010): 619-23. https://doi. org/10.1257/aer.100.2.619.

BPS. 'Angka Kemiskinan Indonesia Sentuh 9,66\%, Terendah Sepanjang Sejarah | Databoks'. Katadata.co.id, 2019.

Choudhury, Masudul Alam, and Md Mostaque Hussain. 'A Paradigm of Islamic Money and Banking'. International Journal of Social Economics 32, no. 3 (2005): 203-17. https://doi.org/10. 1108/03068290510580760.

Dusuki, Asyraf Wajdi. 'Understanding the Objectives of Islamic Banking: A Survey of Stakeholders' Perspectives'. International Journal of Islamic and Middle Eastern Finance and Management 1, no. 2 (2008): 132-48. https://doi.org/10.1108/17538390810880982.

Fahmy Zarkasyi, Hamid. 'Tamaddun sebagai Konsep Peradaban Islam'. Tsaqafah 11, no. 1 (2015): 1-28.

Fajriah, Lily Rusna. 'Angka Kemiskinan Meningkat Tembus 28,51 Juta Orang'. sindonews.com, 2016.

Feldman, Maryann P. 'The Character of Innovative Places: Entrepreneurial Strategy, Economic Development, and Prosperity'. Small Business Economics 43, no. 1 (March 2014): 9-20. https://doi.org/10.1007/ s11187-014-9574-4.

Haniffa, Roszaini, and Mohammad Hudaib. 'Exploring the Ethical Identity of Islamic Banks via Communication in Annual Reports'. Journal of Business Ethics 76, no. 1 (November 2007): 97-116. https://doi.org/ 10.1007/s10551-006-9272-5.

Lubis, Delima Sari. 'Pemberdayaan UMKM Melalui Lembaga Keuangan Syariah sebagai Upaya Pengentasan Kemiskinan Kota Padangsidimpuan'. At-Tijaroh: Jurnal Ilmu Manajemen dan Bisnis Islam 2, no. 2 (2016): 270-85.

Masyita, Dian. 'Why Do People See a Financial System as a Whole Very Important?' Journal of Islamic Monetary Economics and Finance 1, no. 1 (2015): 79-106.

Medias, Fahmi. 'Wakaf Produktif dalam Perspektif Ekonomi Islam'. La_Riba 4, no. 1 (2016): 71-86. https://doi.org/10.20885/lariba. vol4.iss1.art5. 
Meiwanto Doktoralina, Caturida, and Fikki Mutarotun Nisha. 'Mudharabah Deposits Among Conventional Bank Interest Rates, Profit-Sharing Rates, Liquidity and Inflation Rates'. International Journal of Financial Research 11, no. 1 (2020): 25-33. https://doi. org/10.5430/ijfr.v11n1p25.

Mersland, Roy, Trond Randøy, and Reidar Øystein Strøm. 'The Impact of International Influence on Microbanks' Performance: A Global Survey'. International Business Review 20, no. 2 (April 2011): 16376. https://doi.org/10.1016/j.ibusrev.2010.07.006.

Mukminin, Khairul. 'Profit Maximization in Islamic Banking: An Assemblage of Maqasid Shariah Conception'. Profit Maximization in Islamic Banking: An Assemblage of Maqasid Shariah Conception, no. 12 (2019): 1-11. https://doi.org/10.13135/2421-2172/2856.

Mulyadi, Mohammad. 'Peran Pemerintah dalam Mengatasi Pengangguran dan Kemiskinan dalam Masyarakat'. Kajian 21, no. 3 (2016): 221-36.

Nugroho, Lucky, and Ahmad Badawi. 'The Islamic Banking, Asset Quality: "Does Financing Segmentation Matters" (Indonesia Evidence)'. Mediterranean Journal of Social Sciences 9, no. 5 (2018): 221-35. https://doi.org/10.2478/mjss-2018-0154.

Nugroho, Lucky, Ahmad Badawi, and Nurul Hidayah. 'Indonesia Islamic Bank Profitability 2010-2017'. Shirkah Journal of Economics and Business 4, no. 1 (2019): 75-99.

Nugroho, Lucky, Tengku Chandra Husnadi, Wiwik Utami, and Nurul Hidayah. 'Maslahah and Strategy to Establish a Single State-Owned Islamic Bank in Indonesia'. Tazkia Islamic Finance and Business Review 10, no. 1 (2017): 17-33.

Nugroho, Lucky, Nurul Hidayah, and Ahmad Badawi. 'Discourses of Sustainable Finance Implementation in Islamic Bank (Cases Studies in Bank Mandiri Syariah 2018)'. International Journal of Financial Research 10, no. 6 (2019): 108-17. https://doi.org/10.5430/ijfr. v10n6p108.

Nugroho, Lucky, and Dewi. Tamala. 'Persepsi Pengusaha UMKM terhadap Peran Bank Syariah'. Jurnal SIKAP (Sistem Informasi, Keuangan, Auditing Dan Perpajakan) 3, no. 1 (2018): 49-62.

Nugroho, Lucky, Wiwik Utami, and Caturida Meiwanto Doktoralina. 'Ekosistem Bisnis Wisata Halal dalam Perspektif Maqasid Syariah (Halal Tourism Business Ecosystem in the Maqasid Syariah Perspective)'. Perisai : Islamic Banking and Finance Journal 3, no. 2 
(2019): 84-92. https://doi.org/10.21070/perisai.v3i2.1964.

Ozturk, Ilhan, Alper Aslan, and Huseyin Kalyoncu. 'Energy Consumption and Economic Growth Relationship: Evidence from Panel Data for Low and Middle Income Countries'. Energy Policy 38, no. 8 (August 2010): 4422-28. https://doi.org/10.1016/j.enpol.2010.03.071.

Pratama, Yoghi Citra. 'Analisis Faktor-Faktor yang Mempengaruhi Kemiskinan di Indonesia'. Esensi: Jurnal Bisnis Dan Manajemen 4, no. 2 (2014): 210-23.

Rimadhani, Mustika, and Osni Erza. 'Analisis Variabel-Variabel Yang Mempengaruhi Pembiayaan Murabahah Pada Bank Syariah Mandiri Periode 2008.01-2011.12'. Media Ekonomi 19, no. 1 (2011): 27-52.

Rosyid, Maskur, and M. Nurul Irfan. 'Reading Fatwas of MUI a Perspective of Maslahah Concept'. Syariah: Jurnal Hukum Dan Pemikiran 19, no. 1 (2 June 2019): 91-117.

Santana, Paula. 'Poverty, Social Exclusion and Health in Portugal'. In Social Science and Medicine, 55:33-45. Pergamon, 2002. https://doi.org/ 10.1016/S0277-9536(01)00218-0.

Satibi, Elsa, Wiwik Utami, and Lucky Nugroho. 'A Comparison of Sharia Banks and Conventional Banks in Terms of Efficiency, Asset Quality and Stability in Indonesia for the Period 2008-2016'. International Journal of Commerce and Finance 4, no. 1 (2018): 134-49.

TribunJogja. 'Penelitian : Islam Agama dengan Pertumbuhan Paling Cepat di Dunia - Tribun Jogja'. jogja.tribunnews.com, 2017.

Wajdi Dusuki, Asyraf. 'Banking for the Poor: The Role of Islamic Banking in Microfinance Initiatives'. Edited by Masudul Alam Choudhury. Humanomics 24, no. 1 (February 2008): 49-66. https://doi.org/10. $1108 / 08288660810851469$. 
38 || Vol 30, No 1, April 2020 